\title{
ESTIMATION OF WATER REQUIREMENT OF EARLY AND LATE SEASON TOMATO (LYCOPERSICON ESCULENTUM MILL) IN CALABAR, SOUTHEAST NIGERIA.
}

W. UBI AND V. E. OSODEKE

(Received 14, May 2009; Revision Accepted 1, July 2009)

\begin{abstract}
The estimation of water requirements of early and late season tomato was conducted based on 10 years meteorological data at Calabar typical of the humid tropical zone, using the Penman's equation. Results showed that the seasonal crop evapotranspiration (ETo) value for early season tomato (March - July) was $60.8 \mathrm{~mm} /$ day, while that of late season (September - December) was $73.6 \mathrm{~mm} /$ day. The result showed that the water requirement for the late season was $2.0 \%$ higher than the early season tomato. However, water deficit tended to be greater in flowering than at yield formation. The calculated monthly crop coefficient $(\mathrm{Kc} / \mathrm{month})$ values for early season and late season tomato (the initial, crop development, and late season stages) were the same. The Kc values increased from low value at a time of crop emergence to a maximum value during the period when the crop reached full development, and declined thereafter when the crop matured. These results are discussed in light of estimation of water requirement of early and late season of tomato in Calabar.
\end{abstract}

KEY WORDS: Water Requirement, Tomato, Season.

\section{INTRODUCTION}

Tomato (Lycopersicon esculentum, mill) which is perhaps the most important crop in the world (Phene, 1989) and also an important constituent of the daily diet of most Nigerians is not grown commercially in Southern Nigeria. According to FAO (1980) estimates, Nigeria produces about 600,000 metric tones of tomato fruits annually, with the northern savanna zones as the main production centre.

The factors which limit large scale tomato production in the humid tropical lowlands of Nigeria can be traced to inadequate information on the production of the crop. Others include high relative humidity (51$87 \%)$, temperatures $\left(20-33^{\circ} \mathrm{C}\right)$ and high rainfall, averaging $2,162.7 \mathrm{~mm}$ annually (NAPA) meteorological station Calabar (2006). The crop needs well drained and fertile soil with $\mathrm{pH}$ of 5.8-6.8. Tomato probably originated in the peru-Ecurdor region and is now grown in most climatic zones in Africa, tropical Asia, tropical America and the tropics. Cultivars grown include flattered, furrowed fruits, Burpees Best, marmande, marsol rounded fruits Ace, floridade, marglobe, Moneymaker, Moteya, Pearson, elongated fruits: Cambell 28, Heinz 1370, Petomech, Roma (Williams et al 1991). There are also numerous cultivars with firmfleshed fruits of the florida type.

A single tomato plant can produce $2-5 \mathrm{~kg}$, depending on the environment, equivalent to 5-15 tones/ha (FAO 1984).

Water shortage during early flowering reduces the number of fruits and its deficit during yield formation period leads to small fruits and low yield (Raemaekers, 2001, Degras, 2005). In effect, more water supply to the crop and adequate nutrients are required at these growth stages. Ridge (1991) reported that water forms over $90 \%$ by weight of plant tissues hence, plant experiencing drought conditions are unable to grow efficiently. The implication is that the demand for water by crops must be met by water in the soil via the root system, and that the amount of water stored in the soil must be equal to the loss of water by evapotranspiration. The fact that tomato requires adequate amount of water means there is much need to determine the exact water requirements for both seasons as to reasonably know the best management option for greater economic returns to the farmer.

The objectives of the study were to determine crop water requirements and indicate the months with water deficit.

\section{MATERIALS AND METHODS}

The study was conducted at Calabar which lies within latitude $4^{\circ} 37^{\prime} \mathrm{N}$ and $4^{\circ} 41^{\prime} \mathrm{N}$ and longitude $8^{\circ} 9^{\prime} \mathrm{E}$ and $8^{\circ} 12^{\prime} \mathrm{E}$ (White 1964). The humid forest zone of Nigeria. The annual rainfall in Calabar ranges from $1900 \mathrm{~mm}$ to $2200 \mathrm{~mm}$, bimodally distributed with peaks in July and September. The soil is sandy clay loam (Course textured) and classified as an coastal plan soil. (Njoku et al 2001).

The study was based on 10 years (1997-2007) meteorological data collected from the Nigerian Airport Authority meteorological station, Calabar - Cross River State.

The meteorological data are presented in Table 1 and 2 and were used for the computation of the reference or potential crop evapotranspiration (ETo). Reference crop evapotranspiration (ETo) is defined as the rate of evaporation of an extended surface of 15$18 \mathrm{~cm}$ tall green cover, actively growing, completely shading the ground and not short of water (FAO 1986). It therefore represents the climatic evaporation demand and tends to predict the effect of climate on crop. The 
reference crop evapotranspiration (ETo) was therefore calculated based on Penman's equation. This equation is one of the empirical formulae that uses climatic data such as temperature, relative humidity, total wind speed and actual sunshine duration to estimate crop water requirements (FAO 1986). The Penman's equation is stated thus:

$E T o=C[w \times R n+(I-w) \times f(u) \times(e a-e d) \ldots(1)$

Where ea - ed $=$ vapour pressure deficit (mbar)

$\mathrm{F}(\mathrm{u})=$ wind function $(\mathrm{km} /$ day $)$

$\mathrm{W}=$ temperature and altitude depended factor

( $\mathrm{T}$ in ${ }^{\circ} \mathrm{C}$, altitude in $\mathrm{M}$ )

$\mathrm{C}=$ adjustment factor for the ratio $\mathrm{U}$ (day/night)

$\mathrm{Rn}=$ total net radiation in $\mathrm{mm} /$ day

\section{THE GROWTH PERIOD OF TOMATO}

The growth period of tomato at first harvest varies from 90 to 150 days (Phene, 1989). The growth stages were separated into initial, crop development, mid season and late season stages of $30,40,40$ and 25 days respectively (Adelana and Simons, 1980; Phene, 1989 and Quinn, 2000). The crop was assumed to have been sown within the recommended periods for the early and late season cultivation of tomato in the tropics (Thompson, 1996). The late season tomato was assumed to have been planted on the $20^{\text {th }}$ of August and harvested on the $30^{\text {th }}$ of November. The crop coefficients (KC) of $0.45,0.75,1.15$ and 0.8 for initial crop development, mid season and late season growth stages of tomato respectively, were taken from FAO (1986).

The value of Kc varies with crop, development stage of the crop and to some extend with wind speed and humidity. For most crops, the Kc value increases from a low value at time of crop emergence to a maximum value during the period when the crop reaches full development, and then declines as the crop matures (FAO, 1986).

Crop evapotranspiration ( $\left.E T_{\text {crop }}\right)$ refers to conditions when water is adequate for unrestricted growth and development.

Crop evapotranspiration ( $\mathrm{ET}_{\mathrm{m}}$ or $\mathrm{ET}_{\text {crop }}$ ) water determined as: $\mathrm{ET}_{\text {crop }}=\mathrm{ET}_{\mathrm{o}} \times \mathrm{Kc} \ldots$

The $K c$ value at each of the growth stages was calculated to monthly $\mathrm{Kc}$ as

$\mathrm{Kc} /$ month $=\frac{\mathrm{Kc} \text { growth stage } \times \mathrm{N}}{30} \ldots .$.

Where $\mathrm{N}=$ number of days growth lasted in a month and each month was assured to have 30 days

Monthly crop evapotranspiration ( $\mathrm{ET}_{\text {crop }} /$ months) was obtained as a product of $\mathrm{ET}_{\mathrm{o}}$ and $\mathrm{Kc} /$ month. Seasonal $E T_{\text {crop }}$ values were calculated by summing the monthly values.

To calculate actual evapotranspiration for each of the growth stages, apply;

$$
E T_{a}=\underline{S}_{\underline{a}} \underline{D} 1-\left((I-P) e-\underset{(1-p}{E T M} \frac{t}{S_{a} D}+\frac{P}{1-p}\right)
$$

$E T_{0}$ is the actual evapotranspiration for the initial growth stage: 30 days parameters
$\mathrm{ET}_{\mathrm{m}}=4.4 \mathrm{~mm} /$ day
$\mathrm{Sa}=140 \mathrm{~mm}$
$\mathrm{T}=30$ days (initial stage)
$P=0.4$
$\mathrm{D}=0.7$

$$
\begin{aligned}
& \mathrm{Pe}=20 \mathrm{~mm} / \mathrm{months} \\
& \mathrm{ET}_{\mathrm{a}}-140(0.7)(20-(4.4) 30+0.4) \\
& 30(1-0.4) 140(0.7) 1.04 \\
& =\quad 60.88 \mathrm{~mm} / \text { day }
\end{aligned}
$$

For crop development stage 40 days

$\mathrm{T}=40$ days

$\mathrm{ET}_{\mathrm{a}}=140(0.7[20-(4.4) 40+0.4]$

$40(1-0.4) 140(0.7)$ 1-0.4)

$=2.45[20-2.99+0.670$

$=43.32 \mathrm{~mm} /$ day

For late season stage 25 days

$\mathrm{T}=25$ days

$\mathrm{ET}_{\mathrm{a}}=140(0.7)[20-4.4(25)+0.4]$

$25 \quad(1-0.4) 140(0.7) 1-0.4$

$=3.92[20-1.9+0.67]$

$=73.6 \mathrm{~mm} /$ day.

To calculate the total actual water requirement for same crop.

Water requirement $\mathrm{ET}_{\mathrm{m}}=\mathrm{Kc}, \mathrm{ET}_{\text {。 }}$

$\mathrm{ET}_{\mathrm{o}}=\mathrm{C}$ (W.Rs) 2006 climate data

$C=0.98, \mathrm{~W}=0.76 ; \mathrm{Rs}=2.13$

$\mathrm{ET}_{\mathrm{o}}=0.98[0.76 \times 2.13] ; \mathrm{Kc}=0.76($ Table

$=1.6 \mathrm{~mm} /$ day

Water requirement $\mathrm{ETm}=0.76 \times 1.6$

$=1.3 \mathrm{~mm} /$ period.

To indicate the months with moisture deficit for tomato

Moisture deficit is greater in yield formation than vegetative stage i.e. flowering > yield formation > vegetative moisture deficit for the month.

Crop Dev. Stage $>$ mid season stage

Mid season stage $>$ late season stage

Late season stage $>$ initial stage

\section{RESULTS AND DISCUSSION}

Table 1a shows the meteorological data of Calabar in which daily reference crop evaporation $\mathrm{ET}_{0}$ varied from 2.91 to $5.89 \mathrm{~mm} /$ day with a mean of 4.43 $\mathrm{mm} /$ day while the monthly $\mathrm{ET}_{\mathrm{o}}$ varied from 98.73 to $163.42 \mathrm{~mm} /$ month with a mean of $127.6 \mathrm{~mm} / \mathrm{month}$ (Table 1b). The $\mathrm{ET}_{0}$ values were higher in the drier months of January to April but lower in the wetter months of July and August. Similar results were reported by Chukwu (1999), Chukwu and Igbokwe (2001), Iren and Osodeke (2006).

The calculated monthly crop coefficient (Kc/month) values for the early season and late season tomato from the initial, crop development, mid and late season stages were the same (Table 2), and the reported trend is similar to earlier results (FAO, 1986; Messian, 1992) in which Kc values increased from a low value at time of crop emergence to a maximum value during the period when the crop reached full development and thereafter declined when the crop matured. The highest $\mathrm{Kc}$ values were recorded in the month of May and June $(0.83$ and 0.98$)$ for early season and October and November $(0.83$ and 0.98$)$ for the late season tomato. Interestingly, these months coincided with the productive and maturity stages of growth in 
tomato and are found to be the most active growth stage (FAO, 1986; Phene, 1989, Thompson, 1996; Quinn, 2000). The result also showed that the water requirement for the late season tomato was $2.0 \%$ high than the early season tomato. Indeed, the effective rainfall tended to be higher than the water requirement for tomato throughout the growth period of the early season, indicating that water deficit will not be a problem for the good performance of the crop earlier in the season (Cobley and Steele, 1976; Noggle and Fritz, 1992; Reameakers, 2001). The results justified the selection of Calabar, Cross River State, Nigeria as an ideal place for the cultivation of tomato, for greater economic returns to the farmer.

\section{CONCLUSION}

The implication of these findings is that Calabar area of Southeast Nigeria crop water requirement $\mathrm{ET}_{\text {crop }}$ for tomato would be higher during the late season than other periods. Water deficit is greater in yield formation later in the season than early in the season. The reproduction and maturity periods tended to be later in the season in which more rain was expected and higher moisture regime was attained.

Table 1a Meteorological Data of Calabar from 1997 to 2006

\begin{tabular}{|c|c|c|c|c|c|c|c|c|c|c|c|c|}
\hline \multirow[t]{2}{*}{ Months } & \multirow{2}{*}{$\begin{array}{l}\text { Total } \\
\text { Rainfall } \\
(\mathrm{mm})\end{array}$} & \multicolumn{3}{|c|}{ Air Temp. (C) } & \multicolumn{3}{|c|}{ Relative Humility } & \multirow{2}{*}{$\begin{array}{l}\text { Mean Total } \\
\text { wind } \\
\text { speed/ } \\
\text { day }(\mathrm{km} / \mathrm{hr})\end{array}$} & \multirow{2}{*}{$\begin{array}{l}\text { Sunshine } \\
\text { hours }\end{array}$} & \multirow{2}{*}{$\begin{array}{l}\text { Mean day } \\
\text { wind speed } \\
\text { (u day) } \\
\text { (m/sec) }\end{array}$} & \multirow{2}{*}{$\begin{array}{l}\text { Mean night } \\
\text { wind speed } \\
\text { (u night) }\end{array}$} & \multirow[t]{2}{*}{ U day } \\
\hline & & Max & Min & Mean & Max & Min & Mean & & & & & \\
\hline Jan. & 49.4 & 36 & 21 & 28.5 & 67 & 42 & 54.5 & 84.53 & 5.8 & 18.14 & 5.36 & 4.88 \\
\hline Feb. & 3.8 & 38 & 23 & 30.5 & 78 & 48 & 63.0 & 96.68 & 6.5 & 18.18 & 9.38 & 9.34 \\
\hline Mar. & 47.6 & 35 & 24 & 29.5 & 89 & 79 & 84.0 & 112.51 & 6.2 & 21.06 & 12.15 & 2.85 \\
\hline April & 152.4 & 34 & 25 & 29.5 & 90 & 73 & 81.5 & 124.22 & 5.3 & 18.17 & 10.11 & 3.66 \\
\hline May & 425.2 & 32 & 24 & 28.0 & 94 & 76 & 85.0 & 118.15 & 4.1 & 20.36 & 13.52 & 2.52 \\
\hline Jun. & 191.6 & 31 & 24 & 27.5 & 96 & 75 & 89.0 & 114.18 & 3.3 & 18.25 & 12.10 & 2.18 \\
\hline Jul. & 256.4 & 29 & 24 & 26.5 & 95 & 84 & 90.5 & 121.25 & 2.8 & 19.43 & 10.48 & 2.03 \\
\hline Aug. & 510.1 & 28 & 24 & 26.0 & 94 & 87 & 89.5 & 120.36 & 3.4 & 19.74 & 9.37 & 1.98 \\
\hline Sept. & 518.9 & 30 & 23 & 26.5 & 95 & 84 & 89.5 & 119.48 & 3.7 & 18.05 & 8.92 & 2.93 \\
\hline Oct. & 525.8 & 32 & 23 & 27.5 & 96 & 83 & 87.5 & 108.10 & 4.8 & 17.55 & 9.71 & 2.58 \\
\hline Nov. & 32.4 & 33 & 23 & 28.0 & 94 & 81 & & 98.19 & 6.5 & 16.32 & 8.24 & 2.96 \\
\hline Dec. & 36.2 & 33 & 23 & 28.0 & 93 & 72 & 82.5 & 94.47 & 7.8 & 17.24 & 9.02 & 2.95 \\
\hline Total & 2749.8 & 3911.0 & 281.0 & 333.0 & 1081.0 & 884.0 & 897.0 & 1309.41 & 60.2 & 218.49 & 118.36 & 40.46 \\
\hline Mean & 229.15 & 32.58 & 23.4 & 28.0 & 90.08 & 73.7 & 74.8 & 109.12 & 5.0 & 18.20 & 9.86 & 3.37 \\
\hline \multicolumn{13}{|c|}{ Max $=$ Maximum $\quad$ Mix $=$ Minimum } \\
\hline
\end{tabular}

Table 1b Estimation of water requirement of early and late season tomato (Lycopesicum esculentum)

\begin{tabular}{|c|c|c|}
\hline Months & $\mathrm{ET}_{\mathrm{o}} \mathrm{mm} / \mathrm{day}$ & $\mathrm{ET}_{\mathrm{o}} \mathrm{mm} / \mathrm{month}$ \\
\hline Jan. & 5.12 & 141.13 \\
\hline Feb. & 5.71 & 138.17 \\
\hline Mar. & 5.89 & 162.42 \\
\hline April & 4.47 & 156.05 \\
\hline May & 4.69 & 149.35 \\
\hline Jun. & 4.53 & 114.71 \\
\hline Jul. & 2.91 & 98.34 \\
\hline Aug. & 3.87 & 98.73 \\
\hline Sept. & 4.19 & 102.51 \\
\hline Oct. & 3.97 & 119.01 \\
\hline Nov. & 3.98 & 129.30 \\
\hline Dec. & 3.92 & 121.14 \\
\hline Total & 53.24 & 153 \\
\hline Mean & 4.43 & 127.6 \\
\hline
\end{tabular}


Table 2: Monthly crop coefficient (Kc/month) for the early season and late season tomato

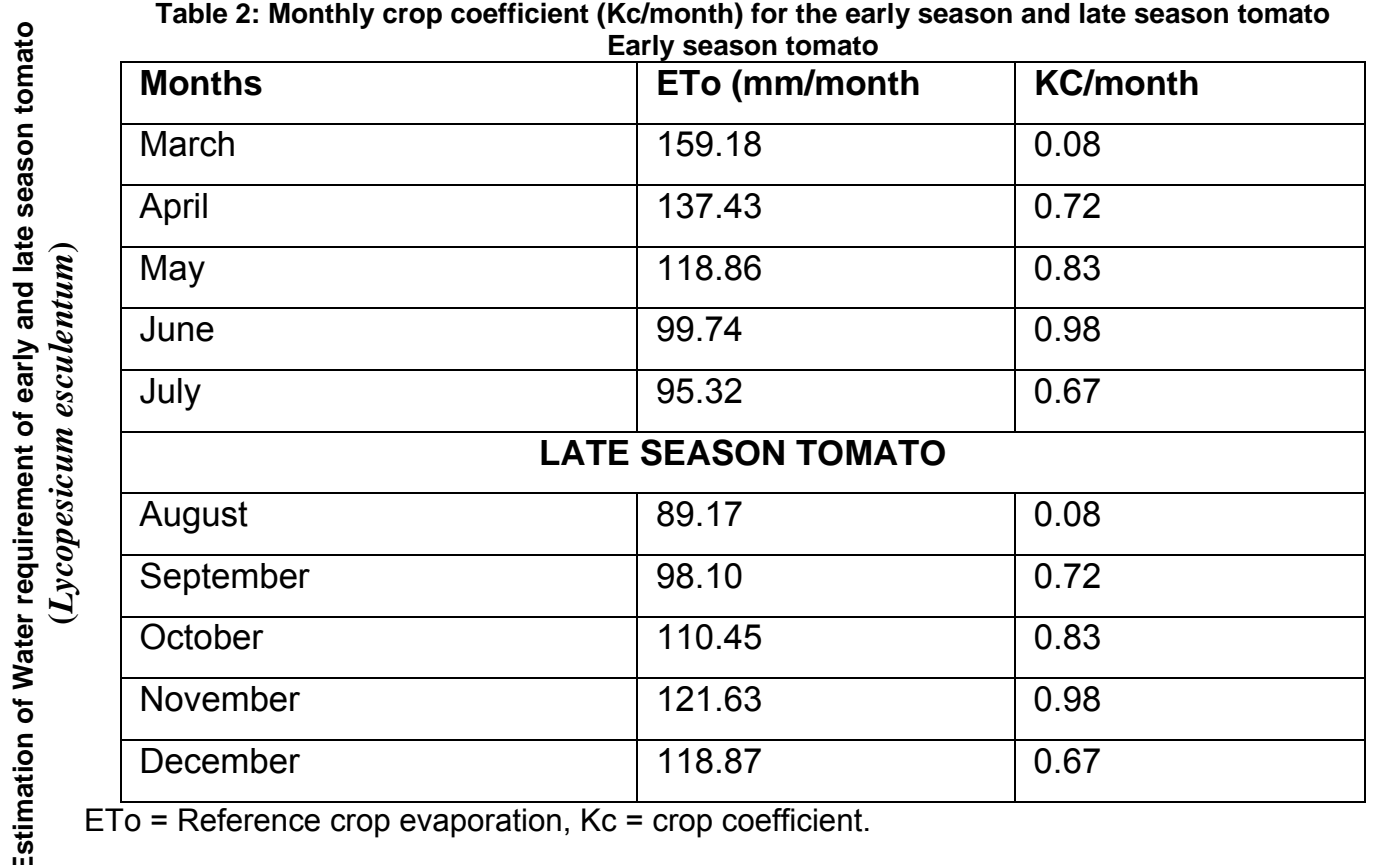

\section{REFERENCES}

Adelama, B. O. and Simons J. A., 1980. An evaluation of some tomato varieties for yield and diseases tolerance in Southwestern Nigeria. Nig. Journal Agric Science 2: 29-34.

Chukwu, G. O., 1999. Estimation of growth requirement of soy bean and groundnut in south eastern Nigeria journal of sustainable agriculture and environment. 1:150-154.

Chukwu, G. O and Igbokwe M. C., 2001. Modeled water requirement of potato (salomen tubersum $\mathrm{L}$ ) on Jos Plateau, Nigeria. Nigerian Agricultural Journal 32:12-18.

Cobley L. S. and Steele, W. M., 1976. An introduction to the Botany of tropical crops $2^{\text {nd }}$ ed. Longman group. London 371p.

Degras, L., 2005. Tropical Root crop CTAI MacMillan, London and Basingstoke.

FAO., 1986. Yield Response to water food and agriculture organization FAL. Irrigation and drainage paper 33:15-117.

Food and Agricultural Organization., 1984. Production year book, FAO Rome. 326p.

Food and Agricultural Organization., 1988. Traditional food plants, FOA food and nutrition paper No. $42 \mathrm{FAO}$, Rome.

Iren, O. B. and Osodeke, V. E., 2006. Estimation of water requirement of early and late season pepper (Capscicum annam) in Umudike, south eastern Nigeria Global Journal of Agric Sc. Vol. 5 NO. 2 95-99.
Messian, C. M., 1992. The tropical vegetable garden. Macmillan, London and Basingstoke.

Njoku, J. C., Okpara D. A. and Asiegba, J. E., 2001. Growth and yield responses of sweet potato to inorganic Nitrogen Journal 32:30-41.

Noggle G. R. and Fritz, G. J., 1992. Introductory plant physiology $2^{\text {nd }}$ ed. Prentice Hall of India, New Delhi 627p.

Phene, C. J., 1989. Water management of tomato in the tropics. Asian vegetable research and development centre. Tomato and pepper production in the tropics. AVRDC. Shanhna Tainam pp. 308-322.

Raemaekers, R. H., 2001. Crop production is tropical Africa directorate general for international cooperation DAK Belgium 1540p.

Quinn., 2000. Factors affecting the production of tomato for the processing industry during different seasons in the northern states of Nigeria. M.Sc thesis Ahmadu Bello University, Zaria, Nigeria.

Ridge, I., 1991. Physiology Hodder and Stoughton Educational London, 372p.

N. A. A., 2006. The Nigeria Airport Authority Meteorological station Calabar.

Thompson, A. k., 1996. Post harvest Technology of fruit and vegetables. Blackwall Science, Oxford.

White, M. G., 1964. Research in Nigeria on the Iroko gall bug (phytolyma. Sp) Nigeria forest information Bulletin (New series) No. 18. Pp. 72

William, C. N., Uzo, J. O. and Peregrine, W. T. H., 1991. Vegetable production in the tropics, Longman Harlow. 